\title{
Integrating Cover Crops and POST Herbicides for Glyphosate-Resistant Palmer Amaranth (Amaranthus palmeri) Control in Corn
}

\author{
Matthew S. Wiggins, M. Angela McClure, Robert M. Hayes, and Lawrence E. Steckel*
}

Field experiments were conducted in 2013 and 2014 in Jackson, TN, to evaluate the efficacy of integrating cover crops and POST herbicides in corn to control glyphosate-resistant (GR) Palmer amaranth. Crimson clover and hairy vetch were planted in the fall and accumulated greater than $1,600 \mathrm{~kg} \mathrm{ha}^{-1}$ aboveground biomass by time of termination. Crimson clover and hairy vetch provided $62 \%$ and $58 \%$ Palmer amaranth control $14 \mathrm{~d}$ before application, respectively. POST herbicide treatments of glyphosate $+S$-metolachlor + mesotrione + atrazine, thiencarbazone-methyl + tembotrione + atrazine, and glyphosate + atrazine were applied when Palmer amaranth reached 15 $\mathrm{cm}$ tall. The herbicide treatments provided greater than 95\% control of Palmer amaranth $28 \mathrm{~d}$ after application. In addition to Palmer amaranth suppression, corn was taller at V5 and V7 following a hairy vetch cover crop. Hairy vetch and crimson clover residues provided early season weed suppression because of biomass accumulation. Palmer amaranth in the nontreated control plots reached $15 \mathrm{~cm} 4$ and $3 \mathrm{~d}$ ahead of the cover-treated plots in 2013 and 2014, respectively. This could potentially increase POST herbicide-application flexibility for producers. Results of this trial also suggest that cover crops alone are not a means of season-long control of GR Palmer amaranth. From a herbicide resistance-management perspective, the integration of cover crops with herbicide mixtures that incorporate multiple sites of action should aid in mitigating the further selection of herbicide resistance in Palmer amaranth.

Nomenclature: Atrazine; glyphosate; mesotrione; S-metolachlor; thiencarbazone-methyl; tembotrione; Palmer amaranth, Amaranthus palmeri (S.) Wats.; corn, Zea mays L.; crimson clover, Trifolium incarnatum L.; hairy vetch, Vicia villosa Roth.

Key words: Cultural weed control, resistance management, weed suppression.

\begin{abstract}
Experimentos de campo fueron realizados, en 2013 y 2014 en Jackson, Tennessee, para evaluar la eficacia de integrar cultivos de cobertura y herbicidas POST en maíz para el control de Amaranthus palmeri resistente a glyphosate (GR). Trifolium incarnatum y Vicia villosa brindaron 62\% y 58\% de control de A. palmeri 14 d después de la aplicación, respectivamente. Los tratamientos de herbicidas POST: glyphosate $+S$-metolachlor + mesotrione + atrazine, thiencarbazone-methyl + tembotrione + atrazine, y glyphosate + atrazine fueron aplicados cuando A. palmeri alcanzó $15 \mathrm{~cm}$ de altura. Los tratamientos de herbicidas brindaron un control de $A$. palmeri superior a 95\%, $28 \mathrm{~d}$ después de la aplicación. Además de la supresión de $A$. palmeri, el maíz fue más alto en los estadios V5 y V7 después del cultivo de cobertura $V$. villosa. $V$. villosa y $T$. incarnatum suprimieron las malezas, temprano durante la temporada, producto de la acumulación de biomasa. En las parcelas testigo sin tratamiento, A. palmeri alcanzó $15 \mathrm{~cm}, 4$ y $3 \mathrm{~d}$ antes que en las parcelas tratadas con cultivos de cobertura, en 2013 y 2014, respectivamente. Esto podría aumentar potencialmente la flexibilidad en la aplicación de herbicidas POST para los productores. Los resultados de este estudio también sugieren que los cultivos de cobertura solos no son aptos para alcanzar un control de A. palmeri GR durante toda la temporada de crecimiento. Desde una perspectiva de manejo de resistencia a herbicidas, la integración de cultivos de cobertura con mezclas de herbicidas que incorporan múltiples sitios de acción debería ayudar a mitigar la selección adicional de resistencia a herbicidas en $A$. palmeri.
\end{abstract}

Corn is the most widely cultivated crop in the United States, with more than 37 million ha planted (USDA-NASS 2014). In-season weed

DOI: 10.1614 /WT-D-14-00145.1

* Graduate Research Assistant, Associate Professor, Professor, and Professor, Department of Plant Sciences, University of Tennessee, 605 Airways Blvd., Jackson, TN 38301. Corresponding author’s E-mail:1steckel@utk.edu control is essential for producing a successful corn crop. Glyphosate-resistant (GR) weeds continue to be the most challenging weeds to manage in U.S. corn, specifically GR Palmer amaranth (Culpepper and York 1998; Klingaman and Oliver 1994).

Palmer amaranth is a dioecious, summer-annual species that is native to the desert southwest region of the United States (Franssen et al. 2001; Sauer 
1957). Despite its origin, Palmer amaranth is able to survive in many diverse environments because of its biological characteristics (Klingaman and Oliver 1994; Sellers et al. 2003). Palmer amaranth has a lengthy germination window, robust growth habit, and is a prolific seed producer (Bond and Oliver 2006; Horak and Loughin 2000; Keeley et al. 1987; Sellers et al. 2003). These characteristics make control of this weed difficult.

Additionally, herbicide resistance complicates management. Presently in the United States, Palmer amaranth biotypes have been confirmed with resistance to acetolactate synthase (ALS)-inhibiting herbicides, dinitroanilines, 4-hydroxylphenylpyruvate dioxygenase (HPPD)-inhibiting herbicides, atrazine, and glyphosate (Heap 2014). To date, glyphosate-resistant Palmer amaranth has been confirmed in many U.S. states, and in most cases, these biotypes are also resistant to ALS-inhibiting herbicides (Bond et al. 2006; Culpepper and York 1998; Heap 2014; Wise et al. 2009). Moreover, biotypes resistant to atrazine and HPPD-inhibiting herbicides have been documented in a number of U.S. states (Heap 2014).

Atrazine and HPPD-inhibiting herbicides are commonly used for weed control in corn and are effective in controlling GR weeds, including Palmer amaranth (Sutton et al. 2002; Swanton et al. 2007; Vyn et al. 2006). Atrazine can be applied PRE or POST alone or in tank-mixtures with several herbicides (Walsh et al. 2012). The HPPDinhibiting herbicides have become popular among corn producers because of their broad-spectrum weed control, flexible application timings, tank-mix compatibilities, and crop safety (Bollman et al. 2008; Stephenson and Bond 2012; Walsh et al. 2012). However, this widespread adoption and repeated use of atrazine and HPPD-inhibiting herbicides is a concern because biotypes with resistance to these herbicides have been confirmed in the U.S. states of Georgia, Illinois, Iowa, Nebraska, and Texas (Heap 2014).

Mechanical and cultural control methods are commonly used in addition to herbicides to aid in weed control. Tillage and cultivation are frequently used for seedbed preparation and for in-season weed control (Edmisten et al. 2010). However, no-tillage corn production is widely used in the United States where soils are prone to erosion (Duke and Powles 2009; Fernandez-Cornejo and Caswell 2006; Young
2006). Cultural control methods, such as crop rotation, narrow row spacing, higher plant populations, and high-residue cover crops, are all practices that can be integrated into a system for the management of GR weeds. Currently, the U.S. Natural Resources Conservation Service is promoting the use of cover crops and is offering a cost-share program to help provide incentive to use cover crops as part of a conservation tillage system (Anonymous 2014; Price et al. 2012).

Winter-annual cover crops have long been used as a conservation tillage practice to prevent soil erosion and water runoff and to improve soil structure, soil quality, organic carbon, and nitrogen (Krutz et al. 2009; Teasdale 1996). However, recent interest in cover crops is primarily attributed to the potential for early season weed control (Norsworthy et al. 2011; Price et al. 2012). Cover crops have provided some suppression of early season weeds in several crops, including cotton (Gossypium hirsutum L.), corn, and soybean [Glycine max (L.) Merr.] (Reddy 2001; White and Worsham 1990). Cover crop residues can reduce available light and moisture to germinating weeds, creating an unfavorable growing environment (Teasdale 1996). Even though cover crops suppress many winter-annual weed species during the early spring, cover crop residues typically do not provide total season-long weed control for summer crops (Teasdale 1996). Herbicides are commonly needed in combination with cover crop residues to achieve adequate weed control.

Research is limited in the area of cover crop residue and POST herbicide integration for controlling Palmer amaranth in corn. The objectives of this research were to (1) determine whether or not the biomass production of crimson clover and hairy vetch suppresses the emergence of GR Palmer amaranth, (2) determine the effect of POST herbicides following cover crops on Palmer amaranth control, and (3) identify which integrated herbicide and cover crop system offers corn producers the most effective Palmer amaranth control.

\section{Materials and Methods}

A field experiment was conducted at the West Tennessee Research and Education Center in Jackson, TN, during the 2013 and 2014 growing seasons (Table 1). The site used for both trials was 
Table 1. Cover and corn planting dates, cover termination date, POST herbicide application date, early season Palmer amaranth control corn harvest dates, total precipitation and growing degree days.

\begin{tabular}{|c|c|c|c|c|c|c|c|}
\hline \multicolumn{2}{|c|}{ Planting dates } & \multirow{2}{*}{$\begin{array}{c}\text { Cover } \\
\text { termination } \\
\text { date }\end{array}$} & \multirow{2}{*}{$\begin{array}{c}\text { POST } \\
\text { herbicide }^{\mathrm{a}} \\
\begin{array}{c}\text { Application } \\
\text { date }\end{array}\end{array}$} & \multirow{2}{*}{$\begin{array}{c}\text { Difference } \\
\text { in time to } \\
\text { reach } \\
15 \mathrm{~cm}^{\mathrm{b}}\end{array}$} & \multirow[b]{2}{*}{ Harvest date corn } & \multirow[b]{2}{*}{$\begin{array}{c}\text { Total } \\
\text { precipitation }^{\mathrm{c}} \\
\end{array}$} & \multirow{2}{*}{$\begin{array}{c}\text { Growing } \\
\text { degree } \\
\text { days }\end{array}$} \\
\hline Cover & Corn & & & & & & \\
\hline & & & & d & & $\mathrm{cm}$ & $\mathrm{GDD}_{10}$ \\
\hline September 28, 2012 & April 10, 2013 & March 22, 2013 & May 23, 2013 & 4 & September 13, 2013 & 81 & 3,424 \\
\hline October 10, 2013 & April 21, 2014 & April 15, 2014 & May 30, 2014 & 3 & September 20, 2014 & 87 & 3,499 \\
\hline
\end{tabular}

infested with a native population of nearly $100 \%$ GR Palmer amaranth that was not known to be resistant to HPPD-inhibiting or triazine herbicides (unpublished data). Corn cultivars P1412-HR and P1319-HR (Pioneer Hi-Bred, 8850 NW 72nd Ave., Johnston, IA 50131) were planted in 2013 and 2014, respectively. The soil type for both sites was a Lexington silt loam (fine-silty, mixed, active, thermic Ultic Hapludalfs). Seed corn was planted 7 $\mathrm{cm}$ deep, with a seed population of 79,000 seed $\mathrm{ha}^{-1}$ into an existing cover crop residue using a notillage planter.

Corn was planted once cover crops were effectively terminated ( $>97 \%$ control). All POST herbicide applications were made across all cover crops and the nontreated control at the same time. The timing of this application was when Palmer amaranth reached a height of $15 \mathrm{~cm}$ in the cover crop-treated plots (Table 1). Therefore, Palmer amaranth was taller in the nontreated control (23 and $21 \mathrm{~cm}$ tall in 2013 and 2014, respectively). Herbicide treatments included glyphosate $+S$ metolachlor + mesotrione + atrazine $(1,048+$ $1048+105+1,671 \mathrm{~g}$ ai ha $\left.{ }^{-1}\right)$, thiencarbazonemethyl + tembotrione + atrazine $(15+75+1,671 \mathrm{~g}$ ai ha $\left.{ }^{-1}\right)$, and glyphosate + atrazine $(1,532+1,671 \mathrm{~g}$ ai ha $\left.{ }^{-1}\right)$. Herbicide applications were applied with a sprayer calibrated to deliver $140 \mathrm{~L} \mathrm{ha}^{-1}$ using AIXR11002 flat-fan nozzles (TeeJet, 1801 Business Park Drive, Springfield, IL 62703, www.teejet.com) set at $186 \mathrm{kPa}$. Crimson clover and hairy vetch were seeded at rates of $17 \mathrm{~kg} \mathrm{ha}^{-1}$ and $22 \mathrm{~kg} \mathrm{ha}^{-1}$, respectively. A no-cover control was included, which was made up of native winter vegetation consisting of henbit (Lamium amplexicaule L.), annual bluegrass (Poa annua L.), and horseweed [Conyza canadensis (L.) Cronq.]. The native winter vegetation in the control plots was typical of that which corn is planted into in the midsouth region of the United States (personal observation). Plots were four rows by $9.1 \mathrm{~m}$, with a row spacing of 76 $\mathrm{cm}$. All data were gathered from the two center plot rows. Each trial was implemented as a randomized block design with a three by four factorial arrangement of treatments with four replications. Treatment factors included a main treatment effect of cover crop species and a secondary treatment of herbicide regime, consisting of atrazine-containing tank-mixes. All production practices, other than weed control and nitrogen recommendations, followed University of Tennessee Extension Service recommendations for corn production (McClure 2010). Current nitrogen recommendations following a legume cover crop that has reached early bloom stage are to reduce nitrogen rate by 67 to 90 $\mathrm{kg} \mathrm{ha}^{-1}$ (Savoy and Joines 2009). However, in this trial, 32-0-0 (N-P-K) liquid nitrogen at a high rate of $202 \mathrm{~kg} \mathrm{ha}^{-1}$ was applied to the entire plot area at the V4 growth stage both years, using a sidedressing implement. Nitrogen rate was not adjusted for residual $\mathrm{N}$ from the legume covers to reduce the potential for cover crop and herbicide treatments to be confounded by nitrogen levels.

The cover crops were planted September 28, 2013, and October 10, 2014, using a no-till drill and allowed to overwinter (Table 1). Cover crop and control plot biomass were measured by harvesting all aboveground plants from a $0.1-\mathrm{m}^{2}$ 
Table 2. Cover crop dry biomass, early season Palmer amaranth control, and corn plant height. ${ }^{\text {a,b }}$

\begin{tabular}{|c|c|c|c|c|c|c|}
\hline \multirow[b]{3}{*}{ Cover crop } & \multirow[b]{3}{*}{ Biomass } & & & \multicolumn{3}{|c|}{ Corn } \\
\hline & & \multicolumn{2}{|c|}{ Palmer amaranth control } & \multicolumn{2}{|c|}{ Plant height } & \multirow[b]{2}{*}{ Yield } \\
\hline & & $14 \mathrm{DBA}$ & $7 \mathrm{DBA}$ & V5 & V7 & \\
\hline & $\mathrm{kg} \mathrm{ha}^{-1}$ & 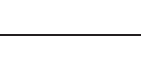 & 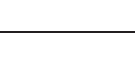 & $\longrightarrow$ & & $\mathrm{kg} \mathrm{ha}^{-1}$ \\
\hline Hairy vetch & $3,090 \mathrm{a}$ & $58 \mathrm{a}$ & $36 \mathrm{ab}$ & $54 \mathrm{a}$ & $138 \mathrm{a}$ & 13,760 \\
\hline $\operatorname{Pr}>F$ & $<0.0001$ & 0.0004 & 0.0432 & $<0.0001$ & $<0.0001$ & NS \\
\hline
\end{tabular}

a Abbreviation: DBA, days before application; NS, not significant.

b Means within a column followed by the same letter are not significantly different according to Fisher's protected LSD at P $<0.05$.

${ }^{\mathrm{c}}$ Areas included in the nontreated check consisted of henbit, annual bluegrass, and horseweed.

quadrat area in each plot. These samples were dried in a forced-air oven at $60 \mathrm{C}$ for $48 \mathrm{~h}$ and weighed. Approximately 3 wk before estimated corn planting, the entire test area was desiccated using paraquat at $851 \mathrm{~g}^{\mathrm{ai} \mathrm{h}} \mathrm{h}^{-1}$ plus $0.25 \% \mathrm{v} / \mathrm{v}$ nonionic surfactant. This herbicide application provided near complete (>97\%) control of all cover crops and the winterannual weeds present in the no-cover control.

Palmer amaranth control was estimated visually each week for $6 \mathrm{wk}$, starting $14 \mathrm{~d}$ before application (DBA) of herbicide treatments. Percentage of control was rated on a scale of 0 (no control) to 100 (complete control). Palmer amaranth density was recorded after visual ratings of weed control had been completed. Density was measured by counting all Palmer amaranth in a $0.5 \mathrm{~m}^{2}$ in two locations of each plot. Because a height difference was observed in corn following vetch, plant heights were measured at the V5 and V7 growth stages. Corn height was measured from the soil line to the whorl leaf.

Corn grain was harvested both years of the study from the two center rows of each plot using a small plot combine. Grain weights were adjusted to $15 \%$ moisture content to calculate yields.

Data were subjected to ANOVA using the PROC MIXED procedure of SAS (version 9.3; SAS Institute; 100 SAS Campus Dr., Cary, NC 27513-2414). ANOVA was used to test for significant main effects and interactions. Means were separated using Fisher's protected LSD test at the 0.05 level of significance. Cover crop species and herbicide treatment were considered fixed effects. Replication and year were treated as random effects as well as any interactions containing those random effects. Designating environments as random effects broadens the possible inferences of the experimental results (Carmer et al. 1989).

\section{Results and Discussion}

Cover Crop Biomass and Early Season Palmer Amaranth Control. Winter-annual weed and cover crop biomass accumulation ranged from 890 to $3,090 \mathrm{~kg} \mathrm{ha}^{-1}$ (Table 2). Both legume cover crops produced more aboveground biomass than the native winter vegetation did. Hairy vetch accumulated the greatest amount of biomass $\left(3,090 \mathrm{~kg} \mathrm{ha}^{-1}\right)$. Other researchers have correlated the accumulation of biomass to the amount of early season weed control (Teasdale1996; Teasdale and Mohler 1993). In both years of this study, crimson clover had less biomass but provided similar weed control compared with hairy vetch. This is possibly due to the slower decomposition rate of crimson clover, which resulted in $22 \%$ more residue than the hairy vetch 7 DBA. This more-persistent cover provided by crimson clover is consistent with other research. Wagger (1989) found that hairy vetch had a lower $\mathrm{C} / \mathrm{N}$ ratio and underwent more rapid decomposition when compared with crimson clover. Similar results were observed in this research, and this response affected the early season weed-control assessments.

At 14 DBA, Palmer amaranth control ranged from 42 to $62 \%$, with crimson clover providing the most suppression. Palmer amaranth control at 7 DBA ranged from 29 to $41 \%$ control to $29 \%$ control. However, crimson clover was the only cover crop that suppressed Palmer amaranth more than the nontreated control. All POST herbicide treatments were made when Palmer amaranth reached $15 \mathrm{~cm}$ in 
Table 3. In-season Palmer amaranth control and density and corn yield. ${ }^{\mathrm{a}, \mathrm{b}}$

\begin{tabular}{|c|c|c|c|c|c|c|}
\hline \multirow[b]{2}{*}{ Herbicide treatments $^{\mathrm{c}}$} & \multicolumn{5}{|c|}{ Palmer amaranth } & \multirow[b]{2}{*}{ Corn yield } \\
\hline & $7 \mathrm{DAA}$ & $14 \mathrm{DAA}$ & $21 \mathrm{DAA}$ & $28 \mathrm{DAA}$ & $\frac{\text { Density }}{28 \mathrm{DAA}}$ & \\
\hline & & & & & No. $\mathrm{m}^{-2}$ & $\mathrm{~kg} \mathrm{ha}^{-1}$ \\
\hline Glyphosate $+S$-metolachlor + mesotrione + atrazine & $96 \mathrm{a}$ & $98 \mathrm{a}$ & $98 \mathrm{a}$ & $99 \mathrm{a}$ & $0 \mathrm{~b}$ & 13,570 \\
\hline Nontreated check & $16 \mathrm{c}$ & $31 \mathrm{c}$ & $26 \mathrm{c}$ & $26 \mathrm{~b}$ & $15 \mathrm{a}$ & 12,950 \\
\hline $\operatorname{Pr}>F$ & $<0.0001$ & $<0.0001$ & $<0.0001$ & $<0.0001$ & $<0.0001$ & NS \\
\hline
\end{tabular}

a Abbreviation: DAA, days after application; NS, not significant.

b Means within a column followed by the same letter are not significantly different according to Fisher's protected LSD at P $<0.05$.

${ }^{c}$ All POST herbicide treatments were applied when Palmer amaranth reached a height of $15 \mathrm{~cm}$ and were mixed with $1,671 \mathrm{~g}$ ai $\mathrm{ha}^{-1}$ of atrazine.

height in the cover-treated plots. The Palmer amaranth had reached a height of $15 \mathrm{~cm} 4$ and $3 \mathrm{~d}$ earlier than the cover-treated plots in 2013 and 2014, respectively (Table 1 ). From a Palmer amaranth resistance-management standpoint, this delay in POST herbicide application timing and reduced weed pressure is beneficial. This system could aid producers in making more timely and effective POST herbicide applications. Unfortunately, the amount of Palmer amaranth control diminished rapidly during the early cropping season, making timely POST herbicide applications essential for season-long control of Palmer amaranth.

In-Season Palmer Amaranth Control. Palmer amaranth control varied throughout the assessment period by POST herbicide treatments (Table 3). Cover crop $(\operatorname{Pr}>F=0.0837)$ and the interaction of cover crop and herbicide treatment $(\operatorname{Pr}>F=$ 0.2267 ) had no effect on Palmer amaranth control 7 DAA. At this assessment, both prepackaged mixtures of herbicides that contained HPPDinhibitors provided the greatest amount of control. The premix containing glyphosate $+S$-metolachlor + mesotrione mixed with atrazine provided $96 \%$ control of Palmer amaranth, whereas the premix containing thiencarbazone-methyl + tembotrione mixed with atrazine provided $91 \%$ control. In this study, glyphosate mixed with atrazine controlled $77 \%$ of Palmer amaranth 7 DAA. Resistance to HPPD-inhibiting herbicides as well as triazines had not been documented on this Palmer amaranth population, so it is likely that the atrazine provided most of the control in the glyphosate mix.
Control of Palmer amaranth 14 and 21 DAA followed a similar trend. POST herbicide had an effect on control 14 and 21 DAA (Table 3), whereas cover crop and the interaction of cover crop and herbicide application had no significant effect $(\operatorname{Pr}>F=0.2117)$. Prepackaged mixtures that contained HPPD-inhibiting herbicides provided greater than $96 \%$ control. Glyphosate plus atrazine controlled Palmer amaranth 89 and $86 \%$ at 14 and 21 DAA, respectively. However, there were no significant differences in Palmer amaranth control among herbicide treatments by 28 DAA. All herbicide treatments provided greater than 95\% control, effectively managing the GR Palmer amaranth present in this trial. Cover crop and the interaction of main effects $(\operatorname{Pr}>F=0.0914)$ had no significant effect on Palmer amaranth control 28 DAA.

Palmer Amaranth Density and Corn Heights. Palmer amaranth densities differed only between the herbicide treated and nontreated control treatments (Table 3). The density of Palmer amaranth in the nontreated control was 15 plants $\mathrm{m}^{-2}$. Cover crop and the interaction effect of cover crop and POST herbicide treatments had no effect on Palmer amaranth densities $(\operatorname{Pr}>F=0.1314)$. Palmer amaranth populations followed a similar trend to visual assessment at 28 DAA. All POST herbicide treatments at this evaluation timing had greater than 95\% control with one or less Palmer amaranth escapes per square meter. Therefore, these results demonstrate that there are effective POST herbicide control options when used alone or as part 
of an integrated weed-management program for controlling GR Palmer amaranth.

Corn plant heights were similar among herbicide treatments $(\operatorname{Pr}>F=0.5442)$ but did differ by cover crop species and ranged from 48 to $54 \mathrm{~cm}$ at the V5 growth stage (Table 2). There was no interaction between main effects at V5 or V7 growth stages. Corn was taller in the hairy vetch treatments. A similar trend was observed at V7. Herbicide treatment had no effect on plant height at V7 (data not shown). Plant height at V7 ranged from 121 to $138 \mathrm{~cm}$, with the tallest corn in the hairy vetch treatment. There was no difference in corn plant height between the crimson clover and the native vegetation control plots. These findings are different than the results of other researchers. Reddy and Koger (2004) found that corn plant height was reduced following hairy vetch. Hairy vetch in this trial accumulated more biomass than seen by Reddy and Koger (2004), suggesting that it fixed more atmospheric nitrogen at termination time, which promoted corn growth (Table 1). Wagger (1989) found that hairy vetch more readily released nitrogen and in greater quantities than crimson clover did when terminated at the same time. Therefore, hairy vetch can be a substantial nitrogen source for corn and can affect plant height if adequate cover crop biomass has been accumulated.

Corn Yield. Corn yield did not differ by cover crop, POST herbicide treatment, or by the interaction of cover crop and herbicide treatments. Adequate heatunit accumulation and precipitation were received during 2013 and 2014 and resulted in a high yield scenario (Table 1). Grain yields were greater than $12,950 \mathrm{~kg} \mathrm{ha}^{-1}$ regardless of cover crop and POST herbicide treatment. Conceivably, differences in corn yield between cover crop treatments and POST herbicide treatments would be more prevalent in a yield-limiting environment, where less than adequate precipitation was received, and in areas of increased Palmer amaranth density. Steckel and Sprague (2004) found that optimum growing conditions mitigated corn yield loss from common waterhemp (Amaranthus rudis Sauer) interference compared with yield-limiting years. Therefore, recommendations are to continue to use POST herbicides to ensure adequate weed control and to prevent yield loss, particularly in dry years. Moreover, the use of cover crops in combination with these POST herbicides can also provide good weed control.
Cover crop residues did provide early season weed suppression because of biomass accumulation. Palmer amaranth in the nontreated control plots reached $15 \mathrm{~cm} 4$ and $3 \mathrm{~d}$ ahead of the cover treated plots in 2013 and 2014, respectively. This could potentially increase POST herbicide application flexibility for growers by delaying Palmer amaranth emergence. Results of this trial suggest that cover crops alone are not a means of season-long control of GR Palmer amaranth. It is essential to integrate timely POST applications and herbicides that act at multiple sites of action with cultural weed control tactics to ensure season long Palmer amaranth control. Corn yield was not affected by cover crop or POST herbicide treatments. The herbicide treatments in this trial, especially those containing HPPD-inhibiting herbicides, were very effective in controlling GR Palmer amaranth. The POST herbicide treatment of glyphosate in combination with atrazine was effective in controlling Palmer amaranth. However, this combination has only one effective site of action to control GR Palmer amaranth. Palmer amaranth biotypes resistant to atrazine are present in many U.S. states (Heap 2014). As corn production increases in the midsouth United States (USDA 2014), the reliance on atrazine alone for controlling GR Palmer amaranth is concerning. From an herbicide-resistance management perspective, additional weed control options, such as using prepackaged herbicide mixtures with multiple sites of action and high residue cover crops, should aid in mitigating the further selection of herbicide resistant biotypes of Palmer amaranth.

\section{Acknowledgments}

The authors would like to thank Kelly Barnett, Patricia Brawley, Ernest Merriweather, Garret Montgomery, and Whitney Crow for their assistance in establishment, maintenance, and harvest of these trials.

\section{Literature Cited}

Anonymous (2014) 2014 Environmental Quality Incentives Program: Cover crop requirements in Tennessee. Natural Resource Conservation Service of Tennessee [Online]. Available at http://www.nrcs.usda.gov/wps/portal/nrcs/detail/tn/ programs/financial/eqip/?cid=nrcs141p2_016426. Accessed August 8, 2014 
Bollman JD, Boerboom CM, Becker RL, Fritz VA (2008) Efficacy and tolerance to HPPD-inhibiting herbicides in sweet corn. Weed Technol 20:267-274

Bond JA, Oliver LR (2006) Comparative growth of Palmer amaranth (Amaranthus palmeri) accessions. Weed Sci 54:121126

Bond JA, Oliver LR, Stephenson DO IV (2006) Response of Palmer amaranth (Amaranthus palmeri) accessions to glyphosate, fomesafen, and pyrithiobac. Weed Technol 20:885-892

Carmer, SG, Nyquist WE, Walker WM (1989) Least significant differences for combined analysis of experiments with two or three-factor treatment designs. Agron J 81:665-672.

Culpepper AS, York AC (1998) Weed management in glyphosate-tolerant cotton. J Cotton Sci 2:174-185

Duke SO, Powles SB (2009) Glyphosate-resistant crops and weeds: now and in the future. Agbioforum 12:346-347

Edmisten KL, Yelverton FH, Spers JF, Bowman DT, Bacheler JS, Koenning SR, Crozier CR, Meijer AD, Culpepper AS (2010) Cotton information. NCSU Cooperative Extension Publication. http://ipm.ncsu.edu/Production_Guides/Cotton/ contents.pdf. Accessed August 14, 2014

Fernandez-Cornejo J, Caswell M (2006) The first decade of genetically engineered crops in the United States [electronic record]. Econ Inf Bull 11, $36 \mathrm{p}$

Franssen AS, Skinner DZ, Al-Khatib K, Horak MJ, Kulakow PA (2001) Interspecific hybridization and gene flow of ALSresistance in Amaranthus species. Weed Sci 49:598-606

Heap IM (2014) International Survey of Herbicide Resistant Weeds. http://www.weedscience.org/summary/Species.aspx. Accessed August 14, 2014

Horak MJ, Loughin TM (2000) Growth analysis of four Amaranthus species. Weed Sci 48:347-355

Keeley PE, Carter CH, Thullen RJ (1987) Influence of planting date on growth of Palmer amaranth (Amaranthus palmeri). Weed Sci 35:199-204.

Klingaman TE, Oliver LR (1994) Palmer amaranth (Amaranthus palmeri) interference in soybeans (Glycine max). Weed Sci 42:523-527

Krutz LJ, Locke MA, Steinriede RW Jr (2009) Interactions of tillage and cover crops on water, sediment, and pre-emergence herbicide loss in glyphosate-resistant cotton: implications for the control of glyphosate-resistant weed biotypes. J Environ Qual 38:487-499

McClure, AT (2010) Planting Corn in Tennessee. Knoxville, TN: University of Tennessee Extension Bull W077

Norsworthy JK, McClelland M, Griffith G, Bangarwa SK, Still J (2011) Evaluation of cereal and Brassicaceae cover crops in conservation-tillage, enhanced glyphosate-resistant cotton. Weed Technol 25:6-13

Price AJ, Balkcom KS, Duzy LM, Kelton JA (2012) Herbicide and cover crop residue integration for Amaranthus control in conservation agriculture cotton and implications for resistance management. Weed Technol 26:490-498

Reddy KN (2001) Effects of cereal and legume cover crops residues on weeds, yield, and net return in soybean (Glycine max). Weed Technol 15:660-668

Reddy KN, Koger CH (2004) Live and killed hairy vetch cover crop effects on weeds and yield in glyphosate-resistant corn. Weed Technol 18:835-840
Sauer JD (1957) Recent migration and evolution of the dioecious amaranths. Evolution 11:11-31

Savoy HJ, Joines DK (2009) Lime and Fertilizer Recommendations for the Various Crops of Tennessee. University of Tennessee BESS Info 100. https://ag.tennessee.edu/spp/ SPP\%20Publications/chap2-agronomic_mar2009.pdf. Accessed November 3, 2014

Sellers BA, Smeda RJ, Johnson WG, Kendig JA, Ellersieck MR (2003) Comparative growth of six Amaranthus species in Missouri. Weed Sci 51:329-333

Steckel LE, Sprague CL (2004) Common waterhemp (Amaranthus rudis) interference in corn. Weed Sci 52:359-364

Stephenson DO IV, Bond JA (2012) Evaluation of thiencarbazone-methyl- and isoxaflutole-based herbicide programs in corn. Weed Technol 26:37-42

Sutton P, Richards C, Buren L, Glasgow L (2002) Activity of mesotrione on resistant weeds in maize. Pest Manag Sci 58:981-984

Swanton CJ, Gulden RH, Chandler K (2007) A rationale for atrazine stewardship in corn. Weed Sci 55:75-81

Teasdale JR (1996) Contribution of cover crops to weed management in sustainable agricultural systems. J Prod Agric 9:475-479

Teasdale JR, Mohler CL (1993) Light transmittance, soil temperature, and soil moisture under residue of hairy vetch and rye. Agron J 85:673-680

[USDA-NASS] U.S. Department of Agriculture-National Agricultural Statistics Service (2014) Acreage. http://usda. mannlib.cornell.edu/usda/nass/Acre//2010s/2014/ Acre-06-30-2014.pdf. Accessed August 14, 2014

Vyn JD, Swanton CJ, Weaver SE, Sikkema PH (2006) Control of Amaranthus tuberculatus var. rudis (common waterhemp) with pre- and postemergence herbicides in Zea mays L. Crop Prot 35:1051-1056

Wagger MG (1989) Time of desiccation effects on plant composition and subsequent nitrogen release from several winter annual cover crops. Agron J 81:236-241

Walsh MJ, Stratford K, Stone K, Powles SB (2012) Synergistic effects of atrazine and mesotrione on susceptible and resistant wild radish (Raphanus raphanistrum) populations and the potential for overcoming resistance to triazine herbicides. Weed Technol 26:341-347

White RH, Worsham AD (1990) Control of legume cover crops in no-till corn (Zea mays) and cotton (Gossypium hirsutum). Weed Technol 4:57-62

Wise AM, Grey TL, Prostko EP, Vencill WK, Webster TM (2009) Establishing the geographical distribution and level of acetolactate synthase resistance to Palmer amaranth (Amaranthus palmeri) accessions in Georgia. Weed Technol 23:214220

Young BG (2006) Changes in herbicide use patterns and production practices resulting from glyphosate-resistant crops. Weed Technol 21:301-307

Received December 11, 2014, and approved March 27, 2015. 